\title{
Impacts of Indiscriminate Mining on Agriculture and Biodiversity in the State of Goa in India
}

\author{
Dnyandev C. Talule ${ }^{1}$, Guruprasad R. Naik, \\ ${ }^{1}$ Department of Economics, Shivaji University, Kolhapur (MH), -416 004 India \\ ${ }^{2}$ MES College of Arts and Science, Zuarinagar, Vasco-da-Gama, Goa, India \\ *Corresponding Author: naikguruprasadramkrishna@gmail.com
}

Copyright (C) 2014 Horizon Research Publishing All rights reserved.

\begin{abstract}
As the agro-diversity harbors a great amount of diversity with respect to species diversity, crop diversity, etc which provides a rich amount of a well evolved system over time background support for rich resources. This has facilitated the development of agriculture. However, in Goa in recent years it has been noticed that these systems of ancient nature have itself been threatened due to the intervention of human activities in such and surrounding areas. More particularly the practice of Mining is on a rise for last few decades in Goa, covering huge belt of land and eventually also harming the forest cover of the state. These forests (Western Ghats also form a part of Eastern Forest cover of Goa) have been deep and very rich bio-diversity hot spots in the world and house the diverse flora and fauna. But, due to the constant and prolonged threat of uncontrolled mining activities in the state these forested biodiversity areas are now in deep trouble. Mainly the attempt in the present paper is made to focus on the impact of mining on agricultural and biodiversity of the state of Goa located in the south western part of India. Goa being one of the mineral endowed states in India and the state with no specific mining policy laid down has to face the adversaries of an indiscriminate mining practiced for several decades.
\end{abstract}

Keywords Agro Biodiversity, Productivity, Mining, Sustainability

\section{Introduction}

The state of Goa in India is a land rich in variety of resources that spawn across the state in its dense forests. Being the smallest state of Goa yet it is endowed with beautiful scenic landscapes, waterfalls, temples and other wonders of nature make it a nice place to dive in. It is beautifully situated in South-Western India, bounded by the two states of Maharashtra and Karnataka to its North, East and South and the Arabian Sea enchanting at its West Coast. The soils of Goa are of Lateritic in nature. There are no significant changes occurring in the temperature which makes it an international tourist destination in India. The climate is however pleasant and warm. The monsoon season in the state runs from the month of June to September. The Western Ghats region runs along the eastern length of the state and consists of a wide belt of rich forest, with abundant biodiversity of flora and fauna. The Western Ghats which form most of the eastern Goa have been internationally recognized as one of the Biodiversity hotspots of the world. Goa has 7 wildlife sanctuaries and 1 national park that houses large fauna in the state. $33 \%$ of Goa's geographical area is under government forests of which about $62 \%$ is brought under protected areas (PA) of wildlife sanctuaries and national park.

Agriculture has been shrinking in the economy over the past four decades, offers part-time employment to a sizeable portion of the population. Rice is the main agricultural crop, followed by Areca, Cashew and Coconut. This has happened due to neglect of People towards agriculture due to the unwillingness to put in hard efforts in this field. Industrial sector offers the next source for employment, which houses some of the reputed industries in India.

The fishing industry provides employment for about forty thousand people. Recent official figures indicate a decline of the importance of this sector and also a fall in catch, perhaps coupled with the fact that traditional fishing has given way to large-scale mechanized trawling.

Tourism is Goa's primary industry. It handles $12 \%$ of all foreign tourist arrivals in India. Tourism is somewhat seasonal in character. Apart from the agriculture and tourism, the mining of iron-ore and manganese happened to be instrumental in fetching a good amount of foreign exchange for the state. The advantage such as the natural harbor and navigable perennial rivers has promoted the economy of exploitation of mineral deposits in this state of the country. The unique feature of the mining industry of the state is the option of cheapest transport of ores as compared to other modes of transportation has gained an edge over other areas of mining in the country. This has made Goa as the predominant state of iron-ore exporting from the country. The average annual iron-ore mining of about 15-16 million 
tons for several decades has in fact its negative impact on the state agriculture and biodiversity.

\section{Objectives and Methodology}

Mainly the present paper is aimed at studying of the Impacts of Mining on biodiversity and agriculture of the state of Goa, one of the mineral rich states in India. Also the paper focuses on other impacts of the longstanding mining in the state of Goa such as the impacts on the quality of air, water, rivers and forests, etc. Goa is a state which has an abudendent availability of high value mineral resources such as the iron ore and manganese. All these mineral resources are indiscriminately mined for decades together which have earned huge amounts of income and foreign exchange for the state and the country. But at the same time it also had its strong negative impact on the other sectors of the state aforementioned. The paper makes use of secondary data collected from various sources such as Economic Survey of government of Goa, Mining Report of Ministry of Mines, Government of India and Western Ghats Ecology Expert Panel Report, several other websites such as Directorate of Geology and Mines, Government of Goa, website on Western Ghats, etc. are also accessed.

\section{The Context of Mining in Goa}

Mining has been playing an important role in the economy of Goa. It is foreign exchange earner for the state. Recently, it has been designated as the industry at par with tourism. It has provided trigger to boost the economy of the mining areas of the state. Certain natural factors like the presence of coastline, a very good natural harbour at Marmugao and a number of navigable perennial rivers have promoted the economic exploitation of mineral deposits in the state. Transport of ores by barges is the cheapest option as compared to road and rail transport. Goa is major iron ore exporting state and over $60 \%$ of India's iron ore export is from Goa. In terms of foreign exchange reserves it amounts to nearly Rs. 1000 crore per year. Mining in Goa is done by open-cast method which necessitates the removal of overburden overlying the iron ore formations. On an average about 2.5 to 3 tonnes of mining waste has to be excavated so as to produce a tone of iron ore. The average annual production of iron ore is about 15 to 16 million tonnes, in the process removal of which is about 40 to 50 million of mining waste is generated.

According to the $6^{\text {th }}$ Citizens Report of Centre for Science and Environment (CSE), almost all of India's minerals lie in the regions populated by dense green forests and presence of abundant river systems. The 'State of Forest Report 1999' published by Forest Survey of India states that the total forest cover of Goa has declined from $1424.46 \mathrm{sq}$. km. in 1990 to $1251 \mathrm{sq} . \mathrm{km}$. in the year 1999. However the forest cover still continues to fall. In 2001 due to a change in methodology of forest measurement that included mango, cashew and other horticultural trees and plantations under the forest cover it showed an increase up to $1785 \mathrm{sq}$. km. but this cannot be treated as the actual change in the forest cover. Surprisingly more than 40 mining leases operate in forest areas leading to the destruction of the same in the stat6e of Goa. Majority of the mining areas are located in Bicholim, Sattari, Sanguem and Quepem talukas. There are many approved mining leases in Sanguem talukas which is densely forested. The maximum area under mining is in Sanguem talukas followed by Bicholim, Sattari and Quepem. As the total of 91 mining leases mined and located in $20 \mathrm{sq} . \mathrm{km}$. of the forest areas it has affected the concerned forests severely. Currently there are 26 active mines in forest areas.

Mining has been prevalent since the 1950s and has led to environmental degradation. Mining has completely devastated Goa's pristine forests. According to the Ministry of Mines (2008) in the period of 28 years from 1980 to 2008, around 1,453 hectares of forest land has been diverted for mining activities. Large areas of forests in the state are not classified under government records. These are private forests or community lands, and hence forest clearance is not necessary for mining. The Economic survey of Goa mentioned that around 2, 66,000 sq. km. of government land is being illegally encroached upon by mining companies.

The Energy and Resources Institute (TERI) states that absorb $18 \%$ of Goa's forests have been lost to mining. In majority of the mines, the overburdens are not properly stored and managed hence hugely affecting the forest cover of the state.

The government has not undertaken any effective measures to control land, air and water pollution. The runoffs from the dumps, pit water discharge and the tailing pond overflow account for most of the sediment (TSS) loads in rivers/streams. The worst affected rivers are Bicholim, Mhadei, and Khandepar. Some of the mines have their dumps right on the river banks from which there is run off directly into the rivers during the monsoon. Run offs from dumps has affected about 320 ha. of agricultural land due to silting.

\section{Results and Discussion}

Farmers complain that from growing three crops a year they are reduced to none. Even their cashew plantations are 'affected due to the dust by mining. Plants do not yield any fruits. Villages in Bicholim Taluka have their fields rendered useless, which are choking with mining rejects while dairy farming has been unsustainable since there is no fodder or adequate water available for their animals. In mining areas the agricultural lands, Plantations and other vegetations that thrived in abundance previously are struggling to grow ever since the onset of mining.

\section{Adverse Effects of Mining in Goa}

Mining in the state of Goa has been practiced by 
Open-Cast method and due to dumping of mine overburden has resulted in the Elimination of vegetation in the forest areas and specifically in the Western Ghats. Forest cover to the south of Mollem, the Verlem forest block in the Netravali sanctuary to the northeast of Cotigao is under pressure from manganese mining. The extraction of Iron Ore has caused degradation and pollution of soil, water and air in the closer vicinity of the mined areas. The wells have been observed to have gone dry because of the pumping of water to extract the iron ore from below the water aquifers. Also, it has led to soil erosion and loss of fertility of land. The heavy rainfall during the monsoons leads to surface runoffs of heavy metals and siltation in fields and rivers thereby causing huge agricultural losses and the problems of river water. The state of Goa being the region of heavy monsoon the deposition of silt and runoffs of overburden piled up at the various mining sites have come down in the agricultural fields due to monsoon runoff that has created problems for fertility of the soil. It has resulted in crop loss and fall in the agricultural yield. The destruction of forests in the mining regions that were previously inhabited by vast fauna in the region now is threatened and forced to relocate in far interior regions of very dense forests and some have been killed during the explosions while the mining activities are conducted. Deforestation and loss of forest cover essential for maintaining the temperature balance in the nature have been destroyed. Due to an indiscriminate mining activity now there is rise in the temperature in the state. The overburden and other materials from the pile up at the mining flow down into the rivers. Solid particles run-off into water have created problems of survival and adaptation for various aquatic animals and altering the life at the sea bed and their habitat suffocation in the sea. This is a tragic condition of Mandovi and Zuari, estuaries as $90 \%$ of Goa's mineral ore is transported through them. (Mishra and Reddy, 2009).

\section{Post Mining-Ban Situation in Goa}

The indiscriminate mining of an iron-ore, manganese, coal, aluminum and other minerals across the mineral rich states of India such as the Andhra Pradesh, Maharashtra, Goa, Orissa, Chhattisgarh, Uttaranchal, Zarkhand and Karnataka and the misappropriation while allocating the leases to the private industries by the government attracted a blanket ban on the mining of the Supreme Court of India. Even though the ban on mining has resulted in a sharp slide down of industrial activity and thereby the growth of the country the ban also has its positive impacts on the areas where the mining had its negative impacts. In the case of Goa after the Imposition of Ban on Mining in the state by the Supreme Court of India following the petition filed by Goa Foundation, and the reports by Western Ghats Ecology Expert Panel Report and Commission under Justice M.B.Shah Report, one can observe the immediate positive impacts on various components of the agriculture, forest and biodiversity.
There has been significant improvement in the quality of air since the ban, as the dust by mining trucks has reduced. During mining and the transport activities of ore, there was a lot of dust emission. The dust would form thick layers on plants and trees alongside roads. With the ban on mining, the air pollution in the locations around mining operations has reduced greatly and is a relief to people with houses besides the roads, commuters on the roads and students and teachers in schools. Due to mining the water bodies were polluted but since then, Post the ban on mining, there is an improvement in fresh water bodies and revival of springs was noticed. This is a positive sign and can only improve with the ban in place. Prior to mining ban there was lot of noise as frequent transport of ore from the trucks and heavy vehicles created lot of problems to the local villagers and students and teachers in the schools in the vicinity areas. However, post mining ban the people have reported that, they are enjoying the noise free environment and now can sleep peacefully at night with no trucks plying on the roads and also feel safe travelling on roads. The rampant mining had destroyed a number of rivers and springs. Ever since the ban, "springs that were earlier dry are gaining their flow." Presently, Fishermen along the Mandovi River have observed a rise in the catch of fish and clams. An indication that 'the marine life is spawning as the movement of barges has stopped. Fishermen in Chicalim (downstream of Zuari River) report that they have started extracting mendios (window pane oysters) which were hard to find earlier but are 'breeding now have still not run out of stock. Since the ban on mining, the revival of rivers and wetlands has been reported with increase in fish catch in major rivers of Mandovi and Zuari. (ERC, Goa, India \& Terence Jorge, Hagen De Sa, Pushp Jain, 2013).

\section{Positive Effects of Ban on Vegetation, Plantations and Agricultural Fields}

There has been increase in production of cashew plantations as the amount of dust has reduced ever since the ban on mining. Fields and plantations are giving produce in the form of crops and fruits. Some areas have witnessed immediate recovery in their plantations. With the amount of dust reduced, farmers have begun cultivating their fields growing chilies and other pulses. In Panshem 'a tailing pond of a mine is slowly sprouting green there also is revival in the near destroyed sacred groves community conserved forested areas that contain ancient idols and medicinal trees.' (ERC, Goa, India \& Terence Jorge, Hagen De Sa, Pushp Jain, 2013).

As the mining has come to a standstill therefore due to a reduction in the noise due to traffic and mining operations, wildlife have been venturing farther than before and are sighted more often. For instance; In Pissurlem with the amount of noise reduced Wild Boars, Peacocks, Red Squirrels, Woodpeckers and Rabbits can be spotted in large numbers. In Surla, the local; people reported that there have 
been "different varieties of species that have been noticed since the ban. In Sanguem, it has been reported that leopards and gaurs have been spotted and also increasing their territory, so also the number of owl sightings have increased on a whole. Residents from Surla reported tha they have spotted 25 different bird species since the ban on Mining.' A forest guard from Netravali reports that 'the wildlife are venturing out of the forest over a wider area as compare to before as there is no noise of trucks. Mouse deer which is a rare animal has been sighted and so also 'Pangolin droppings have been spotted. Rare species such as the Malabar Gliding Nymph butterfly endemic to the western ghats, and was believed to be extinct in Pissurlem, 'has been spotted again in a horticultural field in Avalimol. The Southern Bird-wing, India's largest butterfly was also spotted in the first week of November in Goa's largest mining corridor. Sacred groves such as 'Pejalechi Rai' and 'Mharinganachinrai' have revived as 'habitats for various bird species.' (ERC, Goa, India \& Terence Jorge, Hagen De Sa, Pushp Jain, 2013).

\section{Concluding Remarks Suggestions}

Mining activity in the state of Goa should make several changes in the way it is done. The Open-cast method is one of the destructive methods in the industrialized world which is substantially proved by the mining sector of Goa. This demands a replacement by a suitable method which will be less harmful to the environment and surrounding forests, other biodiversity areas and also for the agriculture and human health. Process of mining needs to follow proper legal procedures and should entrust the people that nothing illegal is allowed. Here building a healthy and conducive relationship between people within the mining regions and mine owners is a need of an hour. A mechanism can be established through which proper screening of mining process right from granting lease to the process of mining operation can be monitored in an impartial and transparent way adhering legal framework. For this sound machinery can be established comprising of all the sections of the society. This will enable to undertake the mining activities transparently and by following all the rules and regulations as stipulated by law. Further the mining activity should not be allowed in close proximity to Protected Areas such as forests, Wild Life Sanctuaries, high value agriculture and National Parks. Also a careful assessment needs to be done prior to granting of lease regarding environmental pollution levels and necessary clearance should be given only when all the required regulations are satisfied. This procedure should be completely transparent and strictly abiding by the rules and laws.

Mining and transportation of mineral ore needs to be carefully done to avoid any kind of harmful hazards and pollution being created that would adversely affect the well-being of the society in the state of Goa. Also there needs to be a proper storage of overburden once it is removed for if it is left untreated it results in washing off into fields and river basins due to the rainfall. The effects of have been experienced severely in Goa where several agricultural fields and rivers have been polluted. Water being one of the scarce resources needs to be conserved properly for biodiversity which is dependent on equal balance in the nature of all the existing resources.

\section{Acknowledgements}

The authors acknowledge all the people associated with us in our profession, outside the profession and various government departments that have helped us by providing various inputs by way of making data accessible and for their constructive criticism and suggestions from time to time which helped us in a great way in pursuing this research work. This research work is dedicated to all these people and especially to our seniors who have constantly encouraged us to positively look forward and undertake the research work in our career.

Authors also acknowledge the sincere and constructive criticism for the improvement of this paper by the unanimous referee(s) who in fact have immensely contributed through their suggestions the improvement of this paper.

\section{REFERENCES}

[1] Survey of Environmental and Socio-Economic Impacts of Interim Ban on Mining in Goa, by (EIA Resource and Response Centre, ERC, Goa -India) and Terence Jorge, Hagen De Sa and Pushp Jain.

[2] Prajna Mishra and M. Gopinath Reddy (2009), Mining in Forest Areas - Problems, Causes and Concerns: A Review, July 2009, Research Unit for Livelihoods and Natural Resources and Centre for Economic and Social Studies, Begumpet, Hyderabad, India.

[3] Iron Mining in Goa (INDIA), An Interdisciplinary Study, Universitat Autonoma de Barcelona, July 2013.

[4] Amarendra Das (2009), Regulatory Authority over Minerals: A Case for Review, Economic and Political Weekly, Vol. XXXXIV, No. X, pp. $105-109$.

[5] Gopal Kadekodi (1979), Technological Choices in Iron Ore Mining, Indian Journal of Industrial Relations, Vol. XV, No. I , pp. 51-62

[6] Jus. M.B.Shah (2010), Commission on Illegal Mining in Goa, Government of India, New Delhi, pp. 01-06.

[7] James P. Dorian (1989), The Development of India's Mining Industry, Springer, Vol. XIX, No. II, pp. 145-160.

[8] Ligia Noronha and Subramanya Nair (2005), Assessing Quality of Life in a Mining region, Economic and Political Weekly, Vol. XXXX, No. I, pp. $72-78$.

[9] Madhav Gadgil (2010), Commission on Western Ghats Ecology Expert Panel, Ministry of Environment and Forests, Government of India, New Delhi, pp. 96-105. 
[10] Ratnakar Bhengara (1996), Coal Mining Displacement, Economic and Political Weekly, Vol. XXXI, No. XI, pp. 647 -649 .

[11] Ministry of Mines, Government of India (www.goadmg.gov.in/).
[12] Goa Environmental Society

(http://goaenvis.nic.in/mining.htm).

[13] Director of Mines and Geology, Government of Goa (www.goadmg.gov.in/).

[14] Down to Earth Website (www.downtoearth.org.in/) 